Expl Cell Biol. 1981;49:I-V

\title{
Contents, Vol. 49, 1981
}

Founded 1938 as 'Schweizerische Zeitschrift fur allgemeine Pathologie und Bakteriologie' by A. v. Albertiní, A. Grumbach and H. Mooser, continued as 'Pathologia et Microbiologia'

\section{Editors}

Pathology:

J.R. Rüttner, Zurich

Microbiology:

F. Deinhardt, Munich

Immunology:

H. Ramseier, Zurich

Heterotransplantation:

L. Helson, New York, N.Y.

Differentiation:

A. Wolsky, New York, N.Y.

Co-Editors

Pathology

R. Hess, Berne

M. Kyogoku, Sendai

M.A. Spycher, Zurich

P. Vassalli, Geneva

G. Zbinden, Zurich

Microbiology

H. Baer, Gainesville, Fla.

I. Gresser, Villejuif

A. Harboe, Oslo

J. Lindenmann, Zurich

H. Mäkelä, Helsinki

J. Oxford, London

R. Rott, Giessen

R.G. Webster, Memphis, Tenn.

R. Zinkernagel, Zurich

Immunology H. Binz, Zurich D.G. Braun, Basel E. Diener, Edmonton G.F. Mitchell, Melbourne R.T. Smith, Gainesville, Fla. J. Sprent, Philadelphia, Pa. E. Wecker, Würzburg H. Wigzell, Uppsala

Heterotransplantation

B.C. Giovanella, Houston, Tex.

D.P. Houchens, Columbus, Ohio

I. Lefkovits, Basel

T. Nomura, Kanagawa

CO. Povlsen, Copenhagen 
N.D. Reed, Bozeman, Mont.

J. Rygaard, Copenhagen

S. Shin, Bronx, N.Y.

B.C.M. Sordat, Lausanne

Differentiation

M. Balls, Nottingham

R. Chandebois, Marseille

G. Csaba, Budapest

D.J. Pizzarello, New York, N.Y.

G.V. Sherbet, Newcastle-upon-

Tyne T. Yamada, Lausanne

S. Karger $\cdot$ Basel $\cdot$ München $\cdot$ Paris $\cdot$ London $\cdot$ New York $\cdot$ Sydney

ГP UD

DB

All rights reserved.

No part of this publication may be translated into other languages, reproduced or utilized in any form or by any means, electronic or mechanical, including photocopying, recording,

microcopying, or by any information storage and retrieval system, without permission in writing from the publisher.

S. Karger AG, P.O. Box, CH-4009 Basel (Switzerland) Printed in Switzerland by Thür AG OfГsetdruck, Pratteln

Drug Dosage

The authors and the publisher have exerted every effort to ensure that drug selection and dosage set forth in this text are in accord with current recommendations and practice at the time of publication. However, in view of ongoing research, changes in government regulations, and the constant flow of information relating to drug therapy and drug reactions, the reader is urged to check the package insert for each drug for any change in indications and dosage and for added warnings and precautions. This is particularly important when the recommended agent is a new and/or infrequently employed drug.

Contents Vol. 49,1981

No.1

Analysis of Expression of Human Mammary Epithelial Antigens in Normal and Malignant Breast Cells as the Single Cell Level by Flow Cytofluorimetry

Peterson, J.A.; Bartholomew, J.C.; Stampfer, M.; Ceriani, R.L 1

Inhibition of Mitogen and Specific Antigen-Induced Human Lymphocyte Proliferation by Cadmium

Kastelan, M.; Gerencer, M.; Kastelan, A.; Gamulin, S

Synovial Cell Antigens - Production of Heterologous Anti-Human Synovial Cell Sera and General Reactivities of the Antisera

Sloan, T.B.; Martincic, R.R.; Anderson, B 20

Growth Kinetics of Human Lung Tumours in Nude Mice

Mattern, J.; Haag, D.; Wayss, K.; Volm, M 34 
Establishment and Maintenance of a Human Glioma Trnsplanted Serially to Hereditary

Asplenic-

Athymic (Lasat) Mice

Yamashita, M.; Takeshita, I.; Mannoji, H.; Egami, H.; Ohta, M.; Kitamura, K

Study of Agglutination of Mouse Mammary Carcinoma (FM3A) Cell Induced by Egg Agglutinin oiRana

catesbiana. II. Phytohemagglutinin P and Protamine

Takeda, S.; Kubota, K; Endoh, Y.; Matsuzawa, T 54

Book Review 60

Announcement

60

No. 2

Biochemical Studies of Bone from Diabetic Rats and Rats Bearing Transplanted Pancreatic Islets

Silberberg, R.; Scharp, D.W.; Lesker, P.A 61

Alpha-Fetoprotein and Albumin Synthesis by Heterotransplanted Rat Liver Tumor Cells

Higgins, P.J.; Borenfreund, E 68

The Suppression of Tumorigenicity in Human X Mouse Cell Hybrids. I. Derivation of Hybrid

Clones,

Chromosome Analysis and Tumorigenicity Studies

Chopan, M.; Kopelovich, L 78

Intracranial Growth of Pulmonary Small Cell Carcinoma Cells in Nude Athymic Mice

Chambers, W.F.; Pettengill, O.S.; Sorenson, G.D 90

Nuclear and Mitotic Abnormalities Produced by Cycloheximide in the Newt Egg during

Cleavage and

Their Relationship to the Cell Cycle

Sentein, $\mathrm{P} \quad 98$

In vitro Human Lymphocyte PHA Response - the Heterogenous Effect of Methylazoxymethanol

Acetate

Jenkins, E.C.; Evans, L.A 118

iy Contents

No. 3

Helper T-Cell-Replacing Factors and T-Cell-Growth Factors Produced by Concanavalin AStimulated

and Pokeweed Mitogen-Stimulated Mouse Spleen Cells

Frey, J.R.; Lefkovits, 1

The Suppression of Tumorigenicity in Human X Mouse Cell Hybrids. II. The Relationship between

Tumorigenicity and Parameters of Transformation in vitro

Chopan, M.; Kopelovich, L 132

Growth of Human Colorectal Tumor Xenografts in Immunosuppressed Mice Reconstituted with

Normal

Cells

Kopper, L.; Van Hanh, T.; Hegedüs, C; Lapis, K 141

Immunological Reconstitution of Tumour-Transplanted and Thymus-Grafted Nude Mice

Jacobsen, G.K.; Rygaard, J.; Povlsen, CO 148

Concanavalin A Agglutination Assays in the Multistage Transformation of a Pig Cell Line

Bouillant, A.M.P.; Greig, A.S 154 
Developmental Arrest of Mouse Tooth Germs in vitro by 6-Diazo-5-Oxonorleucine (DON)

Galbraith, D.B.; Wolf, B.L.; Edelson, D.R 162

Experimental Study of Hormone Receptor Development in a Unicellular Model System

Csaba, G.; Németh, G.; Vargha, P 173

No. 4

Interactions between Human Lymphoblastoid Cells and Human Fibroblast Feeder Layers in vitro Delinassios, J.G.; Kottaridis, S.D 177

Glycoprotein Enrichment in Moloney Leukemia Virus Structural Proteins Released from

Interferon-

Treated Cells

Sherman, L; Teitz, Y 185

Synovial Cell Antigens - Differences of Antigen Compositions between Rheumatoid Arthritic

(RA)- and

Non-RA-Derived Synovial Cells Detected with Anti-Synovial Cell Sera

Sloan, T.B.; Martincic, R.R.; Anderson, B 195

Multicellular Tumor Spheroids of Human Colon Carcinoma Origin. Kinetic Analysis of

Infiltration and

in situ Destruction in a Xenogenic (Murine) Host

Lees, R.K.; Sordat, B.; MacDonald, H.R 207

Correlation between in vitro DNA Synthesis, DNA Strand Separation and in vivo Multiplication of

Cancer Cells

Beljanski, M.; Bourgarel, P.; Beljanski, M 220

Book Reviews 232

No. 5

Lysosomal Enzyme Secretion from Human Placental Villi Is Increased by Serum Albumin and $\mathrm{IgG}$

Douglas, G.C 233

Augmentation of Human Thymocyte Proliferative Responses by Retinoic Acid

Sidell, N.; Famatiga, E.; Golub, S.H 239

Contents V

Inhibitory Effects of the Graft versus Host Reaction upon the Development of the Bursa of

Fabricius.

Early Modifications in the Subepithelial Mesenchyma

Gerard, H.; Gerard, A.; Marchal, L 246

Human Hematopoietic Tumors in Nude Mice

Sordillo, P.P.; Hansen, H.; Jhanwar, S.C.; Beck, J.; Lieberman, P.; Helson, L 256

Membrane Surface Properties of Normal and Malignant Cells: Partition in Aqueous Two-

Polymer Phase

Systems

Sherbet, G.V.; Lakshmi, M.S 267

Age-Dependent Inhibition of Growth of Mouse Neuroblastoma Cells by Mouse Brain Extract

Endoh, Y.; Takeda, S.; Matsuzawa, T 272

Tunicamycin-Induced Shape Transformation in RabDit Erythrocytes and Loss of Adhesion in

Limnaea

Embryonic Cells 
Guha, T.; Brahmachary, R.L 278

Review

Protein Degradation in Health and Disease

Hitzig, W.H 283

No. 6

Sarcomere Formation in Dystrophic Skeletal Muscle

Murphy, B.J.; Allen, E.R 285

Distribution of Nuclear Size and DNA Content in Serial Liver Biopsies of Rats Treated with ./VNitroso-

morpholine, Phenobarbital and Butylated Hydroxytoluene

Romagna, F.; Zbinden, G 294

Studies on the Toxicity and Binding Kinetics of Abrin in Normal and Epstein Barr Virus-

Transformed

Lymphocyte Culture-I: Experimental Results - 1

Witten, M.; Bennett, C.E.; Glassman, A 306

Studies on the Toxicity and Binding Kinetics of Abrin in Normal and Epstein Barr Virus-

Transformed

Lymphocyte Culture-I: Experimental Results - 2

Bennett, C.E.; Glassman, A.; Witten, M 319

Studies on the Toxicity and Binding Kinetics of Abrin in Normal and Epstein Barr Virus-

Transformed

Lymphocyte Culture-I: Experimental Results - 3

Witten, M.; Gordon, I.; Bennett, C.E.; Glassman, A 327

Announcement 332

Author Index 333

Subject Index $\quad 335$

Contents Vol. $49 \quad$ after 338 